Kong. Res. J. 4(2): 136-146, 2017

ISSN 2349-2694

Kongunadu Arts and Science College, Coimbatore.

\title{
ETHNOBOTANICAL STUDY OF KNOWLEDGE AND MEDICINAL PLANTS USE BY THE KURUMBA TRIBES IN CHEMMANKARAI, NILGIRI DISTRICT, TAMIL NADU
}

\author{
Saradha, M1* ${ }^{*}$, G. Divya Bhrathi ${ }^{1}$ and S. Paulsamy ${ }^{2}$ \\ ${ }^{1}$ Department of Botany, Nirmala College for Women, Coimbatore - 641018 \\ ${ }^{2}$ Department of Botany, Kongunadu Arts and Science College, Coimbatore - 641029. \\ *E.mail: saradha.bio@gmail.com
}

\begin{abstract}
The present study initiated with an aim to highlight and document the traditional knowledge and medicinal plants used by the Kurumba tribes inhabiting at Chemmankarai area of Nilgiri district, Tamilnadu. During the study selected study area was visited frequently and information was collected through semi directive, open ended interview among the informants of Kurumba tribes. The details on vernacular name of the plant, mode of diagnosis, disease they treat, usage of plants, mode of application were collected. The plants were identified and deposited at the herbaria of Nirmala College for Women, Coimbatore. The results revealed that the total 56 plant species belonging to 31 families and 47 genera have been documented in the present study. The highest number plants being used for fever and wound healing (7), Insect bite, migraine, bath, ulcer, immunity and throat pain (4) followed by joint pain, tooth ache and asthma (3). The habit of the species showed that $68 \%$ of the drugs were obtained from the herbs compared with the other habit plants. The reported potential ethnomedicinal plants could be conserved and further validation need for better utilization and provisions of the documented knowledge.
\end{abstract}

Keywords: Ethnobotany, Kurumba tribe, traditional knowledge and Nilgiri District.

\section{INTRODUCTION}

India is rich in ethnic diversity and indigenous knowledge that has resulted in exhaustive ethanobotanical studies (Uma priya et al 2011). According to the World Health Organization (WHO) about $65-80 \%$ of the world's population in developing countries depends essentially on plants for their primary healthcare due to the poverty and lack of access to modern medicine (Sharma et al., 2010). In Indian medicine systems, Ayurveda, Sidha and Unani entirely and Homeopathy partially depend either on plant materials or their derivatives for treating human ailments (Joseph and Justinraj, 2011).

The Western Ghats of India is one such high bio-cultural diversity region, which is one of the global biodiversity hot-spots (Myers et al., 2000). The Nilgiri district has variegated plants propagating both exotic and native flora of substantial recuperative utility. It consists all in all six ethnic groups of anthropological interest. They are Todas, Kotas, Kurumbas, Irulas, Paniyas and Kattunayakas (Rajan and Sethuraman,1991). Every tribal group in this country is unique in the sense that they are characterized with certain special knowledge and skills about medicinal plants used in their traditional system of medicine to cure a wide range of disease (Rajan et al 2003). They subside on food such has honey, fruits and tubers besides other variety of cereals. New medicinal uses of plant have been continuously reported by several workers in different localities (Ranjith and Ramachandran, 2010). The present work is an effort to document and analyze the traditional knowledge regarding the practice and use of plants in treatment for various ailments by Kurumba tribes of Chemankarai, Nilgiri District, Tamilnadu.

\section{METHODOLOGY}

2.1. Study Area

Blue mountains are some of the most picturesque mountain ranges situated in Southern India. It is located in North Western corner of Tamil Nadu, South India and the district has geographical area of 2,543 sq. kms. Chemmankarai area situated in Coonoor Taluk of the Nilgiri district, Tamil Nadu, India at altitude of 800 to 830 metres above mean sea level (Fig. 1). The places cover a large area of thick forest vegetation which habitats wild animals such as Black panther, Elephants, Deer, Bear, Bison etc. In view of exploitation and conservation of tribal knowledge an attempt has been made to study the ethanobotanical aspect from Chemmankarai area in Coonoor.

\subsection{Kurumba Tribe}

Kurumba tribes are found in the forest area of Chemmankarai, Nilgiri district. They are skilled people in honey collection, food harvesting and 
medicine preparation. They collect medicinal plants from the deep forest area and utilize it efficiently. These people live in forest area in habitat of wild animals and they are able to sense the smell of the animals nearby or on the way. They make money by selling jack fruits, citrus, Guava, coffee bean cultivation, wild chillies etc., to the Burliar shops on the way to Mettupalayam to Ooty. These people build their houses with stones and red soil.

\subsection{Data collection}

The present investigation was carried out from Chemmankarai area of Nilgiri district to get information from the tribal practitioners and also to cross check the information provided by the practitioners during the earlier visits. The survey was conducted during June, 2016 to November, 2016. The medicinal plants growing in natural habitats of Chemmankarai forest was collected, identified and authenticated with the help of valid references (Hooker, 1875-97; Gamble and Fisher, 1935 and Matthew, 1991). At the same time plant species were collected and herbarium sheets were prepared by traditional method and were deposited in Department of Botany, Nirmala College for Women Coimbatore. The details on vernacular name of the plant, mode of diagnosis, disease they treat, usage of plants, mode of administration were collected from the tribal practitioners through direct interviews and oral conversations. The tribal practitioners have a sound knowledge about the medicinal plants around their place to treat the common diseases in family and neighbourhood.

\subsection{Ailment categories}

On the bases of the information gathered from the tribal healers in the study area all the reported ailments were categories (Table 1) viz., kidney stones, cancer, circulatory system, dermatological infection, endocrine disorders, eye infection, fever, gastro intestinal ailment, genito urinary infection, hair problems, piles, poisonous bite, respiratory system disorder and skeleto muscular system disorder.

\section{RESULTS AND DISCUSSION}

\subsection{Documentation of Indigenous ethnomedicinal knowledge}

The Nilgiri Biosphere Reserve is an international biosphere reserve in the Western Ghats and it is very rich in floral and faunal diversity. Many ethnobotany studies have been carried out in the Nilgiri hills, but the outcome of the study have not reached the local and scientific communities to explore further. The results of the present study revealed that the 56 plant species are used by Kurumba tribes for herbal remedy for the treatment of various ailments. These species belonging to 31 families, the most represented being Solanaceae (5), Asteraceae and Oxalidaceae (4), Malvaceae, Piperaceae, Myrtaceae and Rosaceae (3), Arecaceae, Sapindaceae, Caryophyllaceae, Zingiberaceae, Lamiaceae, Euphorbiaceae, polygonaceae, Rutaceae and Fabaceae (2). Among the genera Oxalis (3), Solanum, Piper, Leucas and Rubus (2) are the most represented genera in the studied plants (Table 2).

Table 1. Ailment grouped under by different ailment categories.

\begin{tabular}{|c|c|c|}
\hline Ailment Categories & Biomedical terms & Tamil Terms \\
\hline Cancer & Cancer & Putru noi \\
\hline Circulatory system & $\begin{array}{l}\text { Blood clotting, blood purification, } \\
\text { cholesterol }\end{array}$ & $\begin{array}{l}\text { Ratham kattu, Rayha suthigaripu, } \\
\text { kozhuppu. }\end{array}$ \\
\hline Dermatological infection & $\begin{array}{l}\text { Cuts, wounds, itching, skin } \\
\text { irritation, burning injury }\end{array}$ & $\begin{array}{l}\text { Vettukayam, aripu, thol noi, arinja } \\
\text { pun. }\end{array}$ \\
\hline Endocrine disorders & Diabetes & Neer elivu noi \\
\hline Eye infection & Eye infection & Kan vedanai \\
\hline Fever & Fever, malaria fever & Kachal, Kosu kadi kachal \\
\hline Gastro intestinal ailment & Ulcer, dysentery, pitta & Kudal pun, pittam \\
\hline Genito urinary infection & $\begin{array}{l}\text { Sexual weekness, menstrual } \\
\text { problems, post natal care. }\end{array}$ & Mada vidai kolaru, \\
\hline Hair disease & Hair disease & Thala mudi noi \\
\hline Kidney stones & Kidney stone & Kal \\
\hline Liver problem & Jaundice & Manja kamalai \\
\hline Piles & Hemorrhoids & Mulam \\
\hline Poisonous bite & $\begin{array}{l}\text { Snake bite, centipede bite, bee } \\
\text { bite, insect bite }\end{array}$ & $\begin{array}{l}\text { Pambu kadi, pooran kadu, then } \\
\text { poochi kadi, poochi kadi. }\end{array}$ \\
\hline Respiratory system disorder & Cold, bronchitis, pneumonia fever & Jaladosham, nenju Sali, \\
\hline Skeleto muscular system disorder & $\begin{array}{l}\text { Arthritis, inflammation, muscular } \\
\text { pain. }\end{array}$ & Vatham, veekam, chadai pidipu \\
\hline
\end{tabular}


Table 2. List of commonly used medicinal plants by Kurumba tribes of Chemmankarai, Nilgiri district, Tamilnadu.

\begin{tabular}{|c|c|c|c|c|c|c|c|c|}
\hline $\begin{array}{l}\text { S. } \\
\text { No. }\end{array}$ & $\begin{array}{c}\text { Binomial } \\
\text { Name }\end{array}$ & Family & $\begin{array}{c}\text { Vernacular } \\
\text { name }\end{array}$ & $\begin{array}{l}\text { Life } \\
\text { form }\end{array}$ & $\begin{array}{c}\text { Chemical } \\
\text { constituents }\end{array}$ & $\begin{array}{c}\text { Mode of } \\
\text { administration }\end{array}$ & $\begin{array}{l}\text { Parts } \\
\text { Used }\end{array}$ & Medicinal Uses \\
\hline 1 & $\begin{array}{l}\text { Abutilon } \\
\text { indicum Sweet }\end{array}$ & Malvaceae & Thuthi & Shrub & Abutilin A(1) & $\begin{array}{l}\text { Oral and } \\
\text { External }\end{array}$ & Leaves & $\begin{array}{l}\text { Leaf decoction taken orally in } \\
\text { empty stomach for } 48 \text { days to cure } \\
\text { bleeding piles. Leaf paste and } \\
\text { turmeric are mixed with heated } \\
\text { coconut oil and heated for } 15 \text { - } 20 \\
\text { min, filtered and applied externally } \\
\text { for piles. }\end{array}$ \\
\hline 2 & $\begin{array}{l}\text { Achyranthes } \\
\text { aspera } \\
\text { L. }\end{array}$ & Amaranthaceae & Naayuruvi & Herb & Triterpenoid saponin & Oral & $\begin{array}{l}\text { Root and } \\
\text { Leaves }\end{array}$ & $\begin{array}{l}\text { Root decoction taken orally for } \\
\text { stomach upset. Leaves are cooked } \\
\text { as greens and used to reduce fever. }\end{array}$ \\
\hline 3 & $\begin{array}{l}\text { Aloe vera (L.) } \\
\text { Burm.f. }\end{array}$ & Liliaceae & Kathalai & Herb & Anthraquinone & $\begin{array}{l}\text { Oral and } \\
\text { External }\end{array}$ & Leaves & $\begin{array}{l}\text { The pulp is collected and mixed } \\
\text { with coconut oil, filtered and used } \\
\text { for external application for } \\
\text { wounds. The pulp is taken raw } \\
\text { orally to control white discharge in } \\
\text { women. The plant is cut and } \\
\text { applied on insect sting to avoid } \\
\text { swelling and itching. }\end{array}$ \\
\hline 4 & $\begin{array}{l}\text { Arisaema } \\
\text { tortuosum } \\
\text { (Wall.) Schott }\end{array}$ & Araceae & Naga chedi & Herb & Arisaimenone & External & Tuber & $\begin{array}{l}\text { The paste of tuber is used as } \\
\text { anitidote for veterinary purposes. }\end{array}$ \\
\hline 5 & Bidens pilosa $\mathrm{L}$. & Asteraceae & $\begin{array}{l}\text { Thatha thala } \\
\text { vetti poo }\end{array}$ & Herb & Friedelinol(1) & External & Leaves & $\begin{array}{l}\text { The leaves are crushed and applied } \\
\text { on cut wounds for clotting of blood. }\end{array}$ \\
\hline 6 & $\begin{array}{l}\text { Biophytum } \\
\text { intermedium } \\
\text { Wight }\end{array}$ & Oxalidaceae & $\begin{array}{l}\text { Little tree } \\
\text { plant }\end{array}$ & Herb & Bioflavanoids & External & $\begin{array}{l}\text { Whole } \\
\text { plant }\end{array}$ & $\begin{array}{l}\text { The plant juice is applied on the } \\
\text { injured part and also for bleeding. } \\
\text { Plant paste is applied on forehead } \\
\text { for migraine. }\end{array}$ \\
\hline 7 & $\begin{array}{l}\text { Cardamine } \\
\text { africana } \mathrm{L} .\end{array}$ & Brassicaceae & $\begin{array}{l}\text { Kattu } \\
\text { kadugu }\end{array}$ & Herb & Alkaloid & $\begin{array}{l}\text { External } \\
\text { External }\end{array}$ & $\begin{array}{l}\text { Whole } \\
\text { plant }\end{array}$ & $\begin{array}{l}\text { Used as herbal bath for babies. } \\
\text { Crushed leaves are tied over } \\
\text { wounds to improve healing. }\end{array}$ \\
\hline 8 & $\begin{array}{l}\text { Cardiospermum } \\
\text { halicacabum L. }\end{array}$ & Sapindaceae & $\begin{array}{l}\text { Mudakathan } \\
\text { keerai }\end{array}$ & Climber & $\begin{array}{l}\text { Cyclohexane-1,4,5- } \\
\text { triol-3-one-1-carbolic } \\
\text { acid. }\end{array}$ & $\begin{array}{l}\text { Oral and } \\
\text { External }\end{array}$ & $\begin{array}{l}\text { Whole } \\
\text { plant }\end{array}$ & $\begin{array}{l}\text { The plant is collected and boiled } \\
\text { with pepper water taken to reduce } \\
\text { joint pain and strengthen bones. } \\
\text { The leaves are grinded into paste } \\
\text { with Cissus quadrangularis and }\end{array}$ \\
\hline
\end{tabular}


Herb

Limonene

Oral

Don

$10 \quad$ Centella

asiatica (L.)

Urban

Apiaceae

Vallarai

Herb

Siddiqui BS(1)

Oral
Cestrum

aurantiacum

Lindl.

12 Colacassia esculenta (L.)

Schott

13 Commelina benghalensis $\mathrm{L}$.

14 Cynodon

dactylon (L.)

Pers

15 Dodonaea viscose Jacq

16 Drymaria cordata (L.)

Willd. ex

Schult.

17 Emilia

sonchifolia

(L.)DC.

18 Galinsoga
Solanaceae

Pnari elai

Shrub

Paraquai

Chaman

Herb

keerai

Commelinaceae

Graminae

Sapindaceae

Caryophyllaceae

Asteraceae

Asteraceae
Vellari chedi Shrub

Chick weed Herb

Amala chedi

Arugu

Herb

Anthocyanin

Cyanogenic hyperoside

Oral

External

External

Sphingoglycolipid

Pothu poo Herb

Rhamnetin

Triacontanol
Leaves

Whole

plant

The plant extract is grinded with

rhizome of turmeric and pinch of salt and given internally to cure ulcer. Flower petals are boiled and regularly intaken to cure cancer

The leaf paste is mixed with goat milk to increase memory power.

Leaf powder is mixed with

Solanum nigrum to control mouth ulcer. Leaf powder with empty stomach is taken to control white discharge in women.

The leaves are crushed and applied on cut wounds.

The leaves and tubers are Cooked with fruit of Tamarindus indica.

Leaves The leaf juice with Piper nigrum are orally intaken to reduce fever.

Whole The plant with cumin is boiled in plant water and taken regularly every day morning in empty stomach to cure digestive disorders.

Leaves

The leaf paste is applied externally on broken bones. The leaves are boiled in hot water and used for bath to get rid of body pain.

Whole The plant extract is applied plant externally to odemas in small children.

Whole Plant paste with salt is applied on plant throat to get rid of tonsillitis.

External Leaves 
parviflora Cav.

19 Hedychium

spicatum Sm.in

A.Rees

Hydrocotyle
javanica
Thumb.

21 Ipomoea cairica Sweet

22 Leucas aspera Spr.

L. hirta Spr.

Lamiaceae

Anacardiaceae

24 Mangifera
indica L.

$25 \quad$ Michelia champaca L.

26 Mimosa pudica L.

27 Myristica fragrans Houtt.

$28 \quad$ Nicandra physaloides Gaertn.

29 Oxalis corniculata L.

30 O. latifolia

Zingiberaceae

Myristicaceae

\section{Solanaceae}

Oxalidaceae

Oxalidaceae
Spiked

Herb

$\alpha$ - Terpineol

ginger lilly

External

Oral

Water
penny
worth

Herb

Cardiac glycosides

External

Morning

glory

Thumbai

Climber Ergoline alkaloid

Oral

Herb $\quad \alpha$ and $\beta$ sitosterol

Nasal

Oral

Sema

thumba

Maa maram

Tree

Mangiferin

Liriodenine

Corcetin-

dimethylester

churungi

Jathika

Erythrosurinamensin
Kattu

kathiri

Puli keerai

Puliyan

keerai
Herb Carotenoid

Herb

Herb
Oral

Oral

Oral the body for treating insect sting and other skin inflammation.

The leaves are burnt and the ash is applied over night to cure head

$$
\text { and }
$$

Rhizomes ache. The rhizome powder is mixed with goat milk and used in treating asthma.

Whole The plant juice with ash is mixed

plant and used to treat fever. The paste of plants is used to treat wounds and boils.

Root Root decoction taken internally for urinary infection.

Leaves 1-2 drops of fresh leaf juice are dropped inside the nose to cure one side head ache.

Root Root decoction is used to treat bronchial diseases.

Seed Seed powder is given in empty stomach to get rid of stomach worms.

Leaves Leaves and bark are boiled in and Bark water and used for bath during fever.

Root Root decoction taken orally to cure

kidney stones.

Fruits The fruit are collected and flesh is and made into pickles to cure digestion seeds problems. The seed is scraped with breast milk and given to new born babies to increase immunity.

Seeds Decoction of seed is used to treat fever.

Whole The infusion of the plant is said to plant be a remedy for hook worm.

Leaves The intake of leaf juice of plant treats urinary infection. 


\section{Piperaceae}

Euphorbiaceae and Thonn.

34 peruviana L.

35 Phytolacca octandra

36 Piper mulesua

\section{Solanaceae}

Phytollacaceae

Othu chedi

\section{Epiphytic}

herb

Keezhanalli

Herb

Aristololactam AII(1)

Phyllanthine

External

Oral

Piperaceae

38 Polygonum chinense L.

39 Psidium gujava L.

40 Rhodomyrtus tomentosa $\mathrm{W}$.

41 Ricinus communis $\mathrm{L}$.

\section{Piperaceae}

Polygonaceae

Myrtaceae

Myrtaceae

Euphorbiaceae
Thol

thakkali

Poke weed

Herb

\section{Cuscohygrine}

Phytolaccic acid

Kattu

milagu milagu

Climbing

knot weed

Koiya

Thavuthu

palam

Amma

nakku
Herb

Climber

Piperine

\section{Climber $\quad \alpha$-tocopherol}

Herb

Small

tree

Shrub

Small

tree

\section{Ricinolein}

Squalene

Pentacyclic

triterpenoid guajanoic

$\alpha$-tocopherol

Ricinolein

Oral

Oral

Oral

Oral

Oral

Oral

External

External

External

Sema mullu
Climber
Anthocyanin

\section{Pambu vada Climber Rubiadin}

Mullu palam Climber $\quad \beta$-Carotene

Oral

Oral Sm.

ral

Roxb.

Oral

Leaves

Leaves

Leaves

Fruits

Roots

Seeds

Leaves

Stem

Leaves

Leaves

Seeds

ral

Oral
One hand full of leaves is boiled with one glass of water to reduce fever.

Leaf paste are applied on fore head to cure migraine

The leaves are grinded with fresh goat milk and taken internally every morning in empty stomach to cure jaundice.

Fruits edible

One gram of dried root powder have been used as laxtative. Seed powder is mixed with honey and taken to cure throat infection and cold.

The leaf, seed decoction are used to treat cough, cold, indigestion.

The stem is directly broken and chewed to get rid of dysentery.

Leaves are chewed with clove to get rid of tooth ache.

Fresh leaves are crushed and applied externally on the inflammation to treat tooth ache. Pregnant women intake oil in size of 50 paise coin every day. The oil is applied on boils. The oil with neem is applied on hair to get rid of ring worm disease in head which causes hair fall.

Dried stem powder is mixed with honey and taken for insect bite. The fruits are regularly taken by pregnant women as it increase the hemoglobin count in mother and fetus.

Young Fruits are consumed to increase 
nepalensis Spr.

Ruta Rutaceae

graveolance $\mathrm{L}$.

47
Saraca asoca
(Roxb.) de
Wilde

48 Sida

rhomboidea

Mast.

49 Solanum

nigrum $\mathrm{L}$.

50 Solanum

sisymbrifolium

Lam.

51 Spergula

arvensis L.

52 Spilanthes clava W.

53 Syzigium cumini (L.)

Skeels

54 Trifolium

repens $\mathrm{L}$.

$55 \quad$ Urena lobata L.

Malvaceae

Solanaceae

Solanaceae

Asteraceae

Myrtaceae

Fabaceae

Malvaceae

\section{Asoka}

maram

Caryophyllaceae

Neer

thamarai

Nar chedi

Herb

Herb

Gingerol

Catechin

$$
-
$$

Herb

-

$-$
Zingiberaceae Inchi
External

External

hydrocarbon

Cryptolepinone

Gentisic acid

$\beta$-sitosterol

Spilanthol

Anthocyanins

Oral

Oral

Oral

Oral

Oral

Oral

Oral

External

Oral

Oral

External
Fruits

officinale Rosc
Leaves

The leaves are dipped in heated castor oil and places on swollen wounds and tied over night to reduce swelling.

Leaves The leaf paste applied on skin and fruits externally to cure skin diseases.

The fruits are threaded as chain and tied in hands of new born babies for protect from infection.

Leaves The leaf decoction is taken for 7 days in empty stomach to cure irregular menstruation.

Whole Plant decoction is taken internally plant to cure rheumatism.

Leaves

Fresh leaves are taken raw to cure mouth ulcer.

Leaf decoction is mixed with pepper to reduce fever.

Fruits Fruits edible.

Whole The whole plant is cooked and plant consumed as body cooler.

Flowers The flowers are crushed and placed in place of tooth ache. The seed powder are dried and taken regularly to have control on diabetics.

Whole Boiled with cumin and taken in plant empty stomach to cure ulcer problem.

Whole The twig is cut and soaked in water plant for few days and fibre is obtained. The leaves are grinded and applied on inflammation to reduce pain

Rhizome Rhizome juice is mixed with honey to cure throat infection 
Table 3. Ingredients added for the preparation of herbal medicines by the Kurumba Tribes.

\begin{tabular}{lcc}
\hline \multicolumn{1}{c}{ Botanical names } & $\begin{array}{c}\text { Other plants added in medicinal } \\
\text { preparation }\end{array}$ & Other ingredients added \\
\hline Abutilon indicum & Curcuma longa & Coconut oil \\
Aloe vera & -- & Coconut oil \\
Catharanthus roseus & Curcuma longa & Salt \\
Centella asiatica & Solanum nigrum & Goat milk \\
Colacassia esculenta & Tamarindus indicus & -- \\
Commelina benghalensis & Piper nigrum & -- \\
Cynodon dactylon & Cuminum cyminum & -- \\
Emilia Sonchifolia & -- & Salt \\
Hedychium spicatum & -- & Goat milk \\
Hydrocotyle javanica & -- & Ash \\
Myristica fragrans & -- & Breast milk \\
Phyllanthus amarus & -- & Goat milk \\
Piper mulesua & -- & Honey \\
Psidium gujava & -- \\
Rhodomyrtus tomentosa & Syzygium aromaticum & -- \\
Ricinus communis & Syzygium aromaticum & -- \\
Rubia cordifolia & Azadirachta indica & Honey \\
Rumex nepalensis & -- & Castor oil \\
Solanum nigrum & -- & -- \\
Trifolium repens & -- \\
Zingiber officinale & Piper nigrum & Honey \\
\hline
\end{tabular}
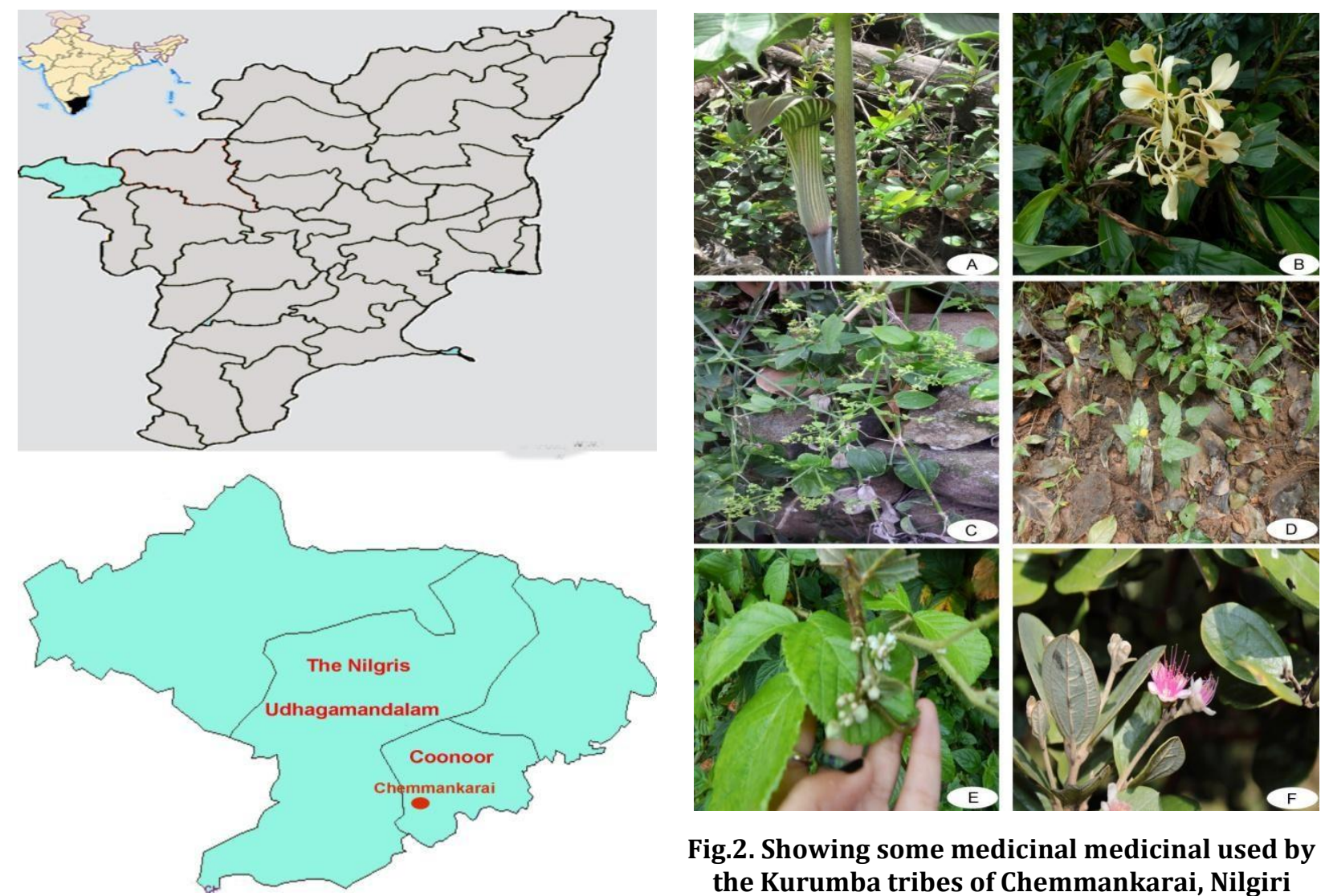

Fig.2. Showing some medicinal medicinal used by the Kurumba tribes of Chemmankarai, Nilgiri

District, Tamilnadu. A- Arisaema tortuosum, B- Hedychium

Fig. 1. Showing the study area of Chemmankarai, Nilgiri District, Tamilnadu.

spicatum, C-Rubia cordifolia, D-Spilanthes clava, E-Rubus ellipticus, F- Rhodomyrtus tomentosa. 


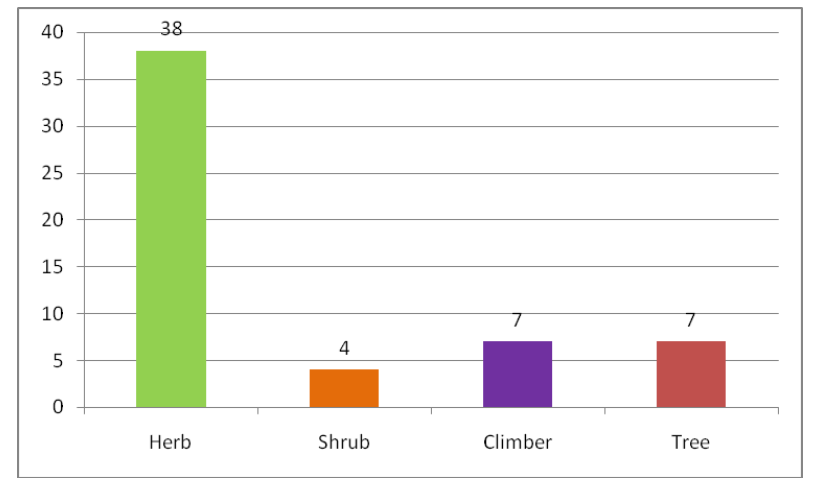

Fig. 3. Analysis of habit with respect to no. of species.

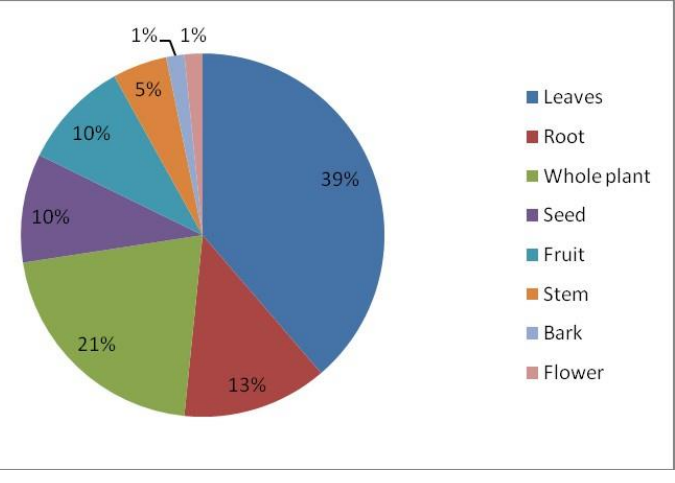

Fig. 4. Statistics of plant parts used.

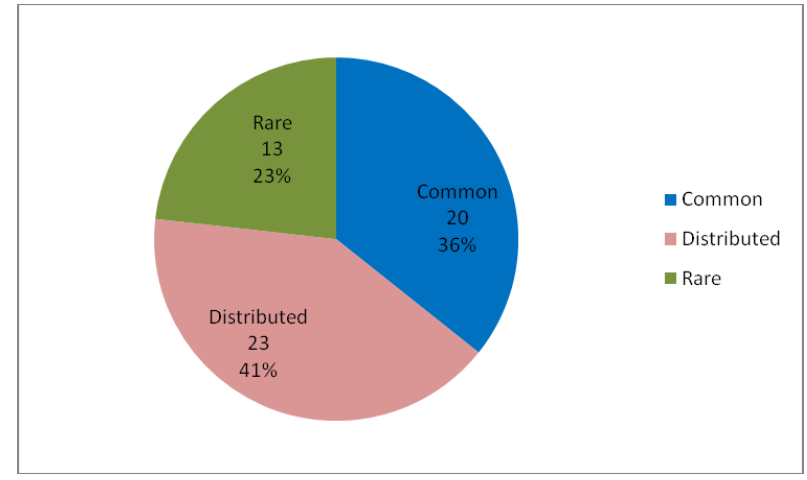

Fig. 5. Status of the plants in the study area.

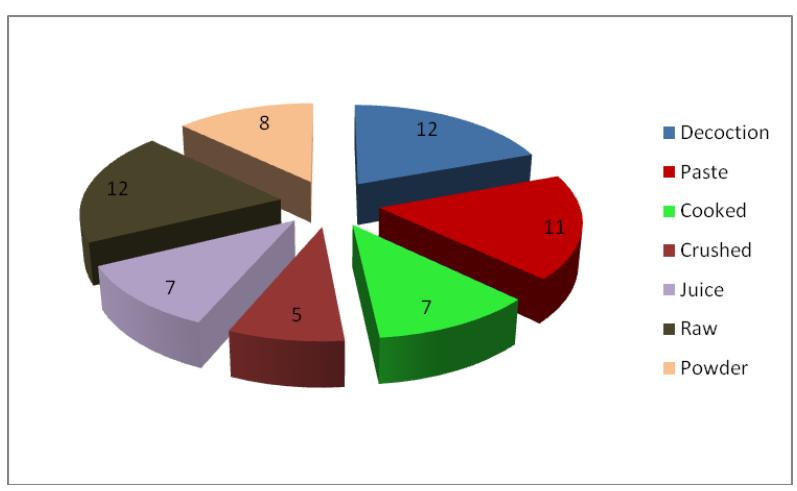

Fig. 6. Categories of Kurumba tribes mode of utilization for the preparation of medicine.

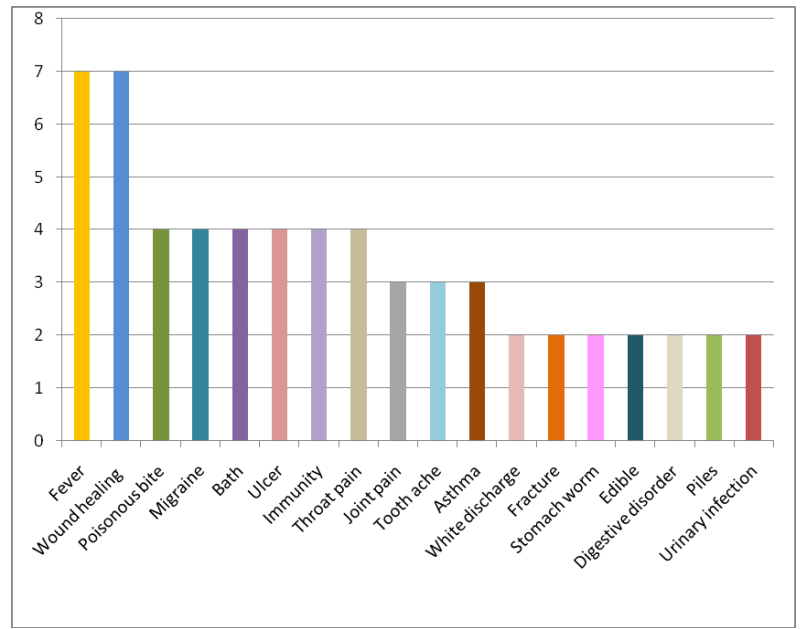

Fig. 7. Plants used for treating various diseases

In the present study more than a single plant used for same ailment, for example Achyranthes aspera, Commelina benghalensis, Hydrocotyle javanica, Michelia champaca, Nicandra physaloides, Oxalis tuberose, Solanum nigrum (fever), Bidens pilosa, Cardamine africana, Cestrum aurantiacum, Hydrocotyle javanica, Rumex nepalensis, Aloe vera (wound) likewise single plant is used for more than 1 disease Achyranthes aspera (fever and stomach problems), Aloe vera (wound, white discharge and insect sting), Biophytum intermedium (bleeding and migraine), Cardamine africana (bath and wound healing), Cardiospermum halicacabum (joint pain and fracture), Catharanthus roseus (stomach ulcer and cancer), Centella asiatica (increase memory,white discharge and mouth ulcer), Dodonaea viscose (fracture and body pain), Hedychium spicatum (Head ache and body pain), Hydrocotyle javanica (fever, boils and wounds), Myristica fragrans (digestive disorder and immunity), Ricinus communis (Ring worm disease and boils), Ruta graveolance (skin disease and immunity) and Solanum nigrum (mouth ulcer and fever). Several studies have reported the plants used for wound healing, fever, stomach problem, itching, skin irritations and other skin diseases in various parts of the world (Harsha et al., 2003; Ayyanar and Ignacimuthu, 2005; Chah et al., 2006 and Saikia et al., 2006) (Table 2 and Fig. 2).

\subsection{Life form and parts used}

Analysis of habit forms indicates 38 plants were herbs, 7 plants were trees, 7 plants were climbers and 4 plants were shrubs (Fig. 3). Observations were made earlier studies on ethnobotany have also been reported that the herbs are the dominant life form in their study area (Ayyanar and Ignacimuthu,2005; Xavier et al, 2014; Kalaiselvan and Gopalan,2014 and Kannadhasan et 
al 2016). According to medicinal preparation of plant parts used, leaves are the most preferable part to prepare medicine (39\%) followed by whole plant $(21 \%)$, root $(13 \%)$, seeds and fruits with $10 \%$, stem (5\%) and bark and flowers with 1\% (Fig. 4). Similarly Xavier et al. 2014 found that leafy crude drug preparations are mostly recommended for ethnomedicine. Fig. 5 shows the number plants used for treating various diseases.

\subsection{Method of preparation and mode of administration of plants}

The preparation and usage of plant parts were categorized as decoction and raw 12\% followed by paste $11 \%$, powder $8 \%$, cooked and juice $7 \%$ and raw $(5 \%$ of the raw materials of plant parts such as fruits, leaf etc.) (Fig. 6). The decoctions were prepared by boiling the plants in water and the water level reduce to about required amount. The preparation of decoction is one of the common ailment practices among some tribal in Tamil Nadu (Ranjith and Ramachandran, 2010; Thirumalai et al., 2012). The paste was prepared by grinding the fresh leaves in water or milk. The mode of administration routes were oral (58\%), external application (41\%) and Nasal (1\%). External application were used to treat piles, skin, wound healing, migraine, broken bones, body pain, head ache, asthma and hairfall. Internal application were preferred to treat fever, ulcer, stomach upset, memory power, digestive disorder, urinary infection, stomach worm, jaundice, cold, tooth ache, rheumatism, diabetics, throat infection and nasal application was for head ache (Fig. 7). The utility of the same was mentioned earlier by Upadhya et al., 2012.

\subsection{Ingredients added}

The medicines were prepared by the Kurumba tribal healers use more than one plants and other ingredients such as honey, goat milk, breast milk, coconut oil, castor oil, salt and ash to improve the tolerability and medicinal property of certain remedies (Table 3). Xavier et al. 2014 have been supported the present findings. Honey and Goat milk are used while intake of prepared medicine in powder forms. Oral medicines are prepared mostly using water, goat milk, breast milk and honey based on the needs.

\section{CONCLUSION}

The tribes of Chemmankarai area have been using numerous medicinal plants for therapeutic purpose since immemorial times. The people depend on these medicinal herbs for the treatment of various diseases such as fever, kidney stone, white discharge in women, asthma, skin disease etc., these plants are used readily as on when needed and so there is need for documentation and conservation of such Medicinal plants.

\section{REFERENCES}

Ayyanar, M. and S. Ignacimuthu, (2005). Traditional knowledge of Kani tribals in Kouthalai of Tirunelveli hills,TamilNadu,India. J.Ethnopharmacol. 102: 246-255.

Chah, K.F., C.A. Eze, C.E. Emuelosi and C.O. Esimone, (2006). Antibacterial and wound healing properties of methanolic extracts of some Nigerian medicinal plants. J. Ethnopharmacol. 104: 164-167.

Gamble and Fisher, (1921-1935). Flora of Presidency of Madras (Adlard and Son Ltd., London) 1-3 12017.

Harsha, V.H., S.S. Hebbar, V. Shripathi and G.R. Hegde, (2003). Ethnomedicobotany of Uttara Kannada District in Karnataka, India, plants in treatment of skin diseases. J. Ethnopharmacol. 84: 37-40.

Hooker, J,D. (1875). Flora of British India. Published under the authority of the secretary of state for India in council. London :L. Reeve Vol I p.465.

Joseph, B. and S. Justinraj, (2011). A comparative study on various properties of five medicinally important plants. Int J Pharm. 7(2): 206- 211.

Kalaiselvan, M. and R. Gopalan, (2014). Ethnobotanical studies on selected wild medicinal plants used by Irula tribes of Bolampatty Valley, Nilgiri Biosphere Reserve (NBR), Southern Western Ghats, India. Asian J. Pharm. Cl. Res. 7(1):22-26.

Kannadhasan, M., S. Valarmathi and K. Raju, (2016). Ethanobotanical study of Medicinal plants by Malaiyali tribes in Pachaimalai Hill Area of Trichirapalli District, Tamil Nadu India. J. Eng. Res. Appl. 6(7): 01-05.

Matthew, K.M. (1991). An excursion flora of central Tamil Nadu. India. New Delhi. Oxford and IBH Publishing Co. Pvt. Ltd.

Myers, N., R.A., Mittermeier, C.G. Mittermeier, A.B. Gustavo, D.A. Fonseca and J. Kent, (2000). Biodiversity hotspots for conservation priorities. Nature 403: 853-858.

Rajan, S. and M. Sethuraman, (1991). Plants used in folk medicine by the Kotas of Nilgiri district, Tamil Nadu. Anc. Sci. Life 10(4): 223-230.

Rajan, S., M, Jayendran and M. Sethuraman, (2003). Medico-ethnobotany: A study on the Kattunayaka tribe of Nilgiri Hills, Tamil Nadu. Nat. Remedies 3(1): 68 - 72. 
Ranjith, N.P and V.S. Ramachandran, (2010). Ethnomedicines of Kurichyas, Kannur district Western Ghats kerala. Ind. J. Nat. Prod. Res. 1(2): 249-253.

Saikia, A.P., V.K. Ryakala, P. Sharma, P. Goswami and U. Bora, (2006). Ethnobotany of medicinal plants used by Assamese people for various skin ailments and cosmetics. J. Ethnopharmacol.106(2):149-157.

Sharma, K.A., R. Kumar, A. Mishra and R. Gupta, (2010). Problems associated with clinical trials of Ayurvedic medicines. Rev. Bras. Farmacogn. Braz. J. Pharmacogn. 20(2): 276-278.
Uma priya, T., A. Rajendran, V. Aravindhan, Binu Thomas and Maharajan, (2011). Ethanobotany of Irula tribes of Palani Hills, Coimbatore, Tamil Nadu. Ind. J. Nat. Prod. Res. 2(2): 250-255.

Upadhya, V., V.H. Harsha, B. Shripad, J.H. Pramod, S.D. Kholkute and G.R. Hegde, (2012). Ethnomedicinal plants used to treat bone fracture from North-Central Western Ghats of India. J. Ethnopharmacol. 142: 557-562.

Xavier, T.F., M. Kannan, L. Lija, A. Auxillia, A.K. Freeda Rose and S. Senthilkumar, (2014). Ethnobotanical study of Kani tribes in Thoduhills of Kerala, South India. J. Ethnopharmacol. 152:78-90. 